\title{
Pengaruh celebrity worship, gaya hidup hedonis, dan kecanduan internet terhadap pembelian kompulsif merchandise band day6 pada online shop Uriharu Id
}

\author{
Hurun Iin Driana, Aniek Indrawati* \\ Universitas Negeri Malang, Jl. Semarang No. 5 Malang, Jawa Timur, Indonesia \\ *Penulis korespondensi, Surel: aniek.indrawati.fe@um.ac.id
}

Paper received: 3-5-2021; revised: 24-5-2021; accepted: 28-5-2021

\begin{abstract}
Abstrak
Tujuan dari penelitian ini adalah untuk mengetahui :1) Pengaruh Celebrity Worship terhadap Pembelian Kompulsif merchandise Band Day6 pada Online Shop Uriharu Id; 2) Pengaruh Gaya Hidup Hedonis terhadap Pembelian Kompulsif merchandise Band Day6 pada Online Shop Uriharu Id; dan 3) Pengaruh Kecanduan Internet terhadap Pembelian Kompulsif merchandise Band Day6 pada Online Shop Uriharu Id. Penelitian ini menggunakan pendekatan kuantitatif dengan jenis penelitian yang digunakan adalah deskriptif dan explanatory. Teknik pengambilan sampel menggunakan teknik purposive sampling dengan jumlah 110 orang pelanggan Uriharu Id. Jenis data dalam penelitian ini adalah data kuantitatif yang merupakan data penelitian berupa angka yang berasal dari kuesioner. Teknik analisis yang digunakan adalah analisis regresi linier berganda. Hasil penelitian menunjukkan bahwa : 1) Terdapat pengaruh positif dan signifikan Celebrity Worship terhadap Pembelian Kompulsif merchandise Band Day6 pada Online Shop Uriharu Id, artinya sikap pemujaan terhadap selebriti (celebrity worship) yang dimiliki pelanggan Uriharu Id yang juga merupakan penggemar band Day6 ini, dapat mendorong mereka untuk melakukan pembelian secara kompulsif dengan melakukan pembelian produk-produk terkait idola; 2) Terdapat pengaruh positif dan signifikan Gaya Hidup Hedonis terhadap Pembelian Kompulsif merchandise Band Day6 pada Online Shop Uriharu Id, artinya Gaya Hidup Hedonis yang dimiliki oleh pelanggan Uriharu Id mempengaruhi mereka untuk melakukan pembelian barang-barang yang kurang dibutuhkan secara terus menerus hanya untuk memuaskan keinginan dan rasa senang mereka, seperti membeli merchandise band Day6 berulang kali pada online shop Uriharu Id; 3) Terdapat pengaruh positif dan signifikan Kecanduan Internet terhadap Pembelian Kompulsif merchandise Band Day6 pada Online Shop Uriharu Id, artinya Kecanduan Internet yang dilakukan oleh pelanggan Uriharu Id dapat menyebabkan mereka melakukan pembelian kompulsif terhadap suatu produk secara online, seperti pembelian merchandise Band Day6 yang dilakukan pada Online Shop Uriharu Id.
\end{abstract}

Kata kunci: Celebrity Worship; Gaya Hidup Hedonis; Kecanduan Internet; Pembelian Kompulsif

\section{Pendahuluan}

Dalam dua dekade terakhir perkembangan budaya Korea sangat pesat dan meluas secara global. Keberadaan tersebut menghasilkan suatu fenomena Korean Wave atau disebut juga dengan Hallyu. Faktor utama yang menyebabkan terjadinya hal tersebut di Indonesia adalah karena perkembangan teknologi yang sangat pesat akibat adanya globalisasi.

Menurut Putri, et al. (2019) Korean wave adalah istilah yang diberikan untuk penyebaran budaya populer Korea melalui produk-produk hiburan seperti drama, musik, style. Larasati (2018) menyatakan bahwa Korean Wave terdiri dari beberapa konten kebudayaan yang menjadi salah satu komoditas ekspor utama bagi Korea Selatan, di antaranya yakni film, drama televisi (K-drama), musik (K-pop) dan K-fashion. 
Sepanjang tahun 2019 twitter telah mengumumkan bahwa Indonesia berada pada peringkat ketiga setelah Thailand dan Korea Selatan, dalam daftar yang paling banyak mentweet tentang artis Kpop. Hal ini menjadikan Indonesia sebagai pasar yang sangat potensial untuk perekonomian Korea Selatan dengan adanya Korean Wave (Egsaugm, 2020).

Dibalik fenomena pemujaan terhadap boyband Korea yang semakin banyak terjadi, terdapat juga beberapa grup band yang namanya sudah mendunia. Salah satunya yaitu band Day6. Band ini dibentuk oleh JYP Entertainment, yang termasuk dalam big three company di Korea Selatan, dengan nama fandomnya yaitu My Day yang diresmikan melalui akun twitter official mereka pada tanggal 7 Juni 2017 (Tyas, 2017).

Ayu dan Astiti (2020) mengatakan bahwa penggemar K-pop sering dianggap berlebihan dalam menyukai idola mereka. Sikap ini disebut sebagai celebrity worship dalam ilmu psikologi. Faktor-faktor yang dapat mendorong individu melakukan celebrity worship adalah usia, keterampilan sosial, dan jenis kelamin. Menurut Maltby, et al. (2003) celebrity worship adalah perilaku obsesi pada individu untuk terlibat secara penuh di setiap kehidupan idolanya, sehingga terbawa dalam kehidupan sehari-hari pada individu tersebut.

Biasanya para penggemar tersebut melakukan berbagai kegiatan yang bertujuan untuk mendukung idolanya. Kegiatan tersebut memerlukan pengorbanan materi ataupun non materi baik dari segi waktu, tenaga maupun dana untuk menyenangkan idolanya. Misalnya dengan mengeluarkan banyak uang untuk membeli tiket konser, album, merchandise, vote, dan produk - produk yang berkaitan dengan idola mereka. Segala bentuk konsumsi berulang yang dilakukan tersebut berkaitan dengan teori compulsive buying dan pemujaan terhadap selebriti. (Setiawan, 2016).

Pernyataan tersebut didukung oleh Putri dan Rositawati (2020) dalam penelitiannya yang menemukan bahwa adanya pengaruh positif celebrity worship terhadap perilaku compulsive buying. Orang-orang dengan celebrity worship cenderung melakukan pembelian secara kompulsif dengan melakukan pembelian produk - produk yang berkaitan dengan idola karena dengan hal tersebut dapat membuat penggemar merasa lebih dekat dengan idolanya (Reeves, et al, 2012).

Menurut Schiffman dan Kanuk dalam Yuniarinto dan Wijaya (2015) Perilaku kompulsif merupakan tindakan konsumsi berlebihan, ketagihan, dan berulang-ulang dengan tujuan mempengaruhi suasana hati untuk lebih bahagia. Konsumen yang mempunyai perilaku kompulsif sering melakukan pembelian untuk meredakan rasa ketidaknyamanan yang disebabkan dari pemikiran ataupun keinginan untuk memiliki sebuah barang (Workman dan Paper dalam Yuniarinto dan Wijaya, 2015).

Seiring banyaknya online shop yang menjual beraneka ragam merchandise Kpop, maka dapat menyebabkan pembelian kompulsif terhadap produk-produk yang terkait dengan idola menjadi semakin tinggi. Tindakan seseorang dalam mengambil keputusan untuk membeli barang bukan hanya karena kebutuhannya, melainkan juga demi pemuasan keinginannya yang dilakukan secara berlebihan, kronis, dan berulang-ulang inilah yang menyebabkan terjadinya suatu pembelian kompulsif (Putri dan Rositawati, 2020).

Kemudian karena adanya globalisasi ini juga berdampak pada perubahan tata nilai hidup manusia yang menjadikan mereka memiliki perubahan sikap ke arah kehidupan yang 
mewah yaitu gaya hidup hedonis atau hedonisme. Gaya hidup seseorang mempengaruhi kebutuhan, keinginan, dan perilakunya termasuk perilaku pembelian mereka terhadap suatu produk.

Nadzir dan Ingarianti (2015) menyatakan bahwa gaya hidup hedonis merupakan suatu pola hidup seseorang yang melakukan aktivitasnya untuk mencari kesenangan hidup, menghabiskan waktunya di luar rumah untuk bersenang-senang dengan temannya, gemar membeli barang yang kurang dibutuhkan, serta selalu ingin menjadi pusat perhatian di lingkungan sekitarnya.

Berdasarkan penjelasan tersebut maka dapat dikatakan bahwa pada remaja dengan gaya hidup hedonis berpengaruh positif terhadap pembelian kompulsif yang dilakukan. Gaya hidup seseorang sangat berpengaruh terhadap perilaku dan tindakan mereka termasuk perilaku pembeliannya. Veenhoven dalam Felicia, dkk (2014) mengatakan individu yang hidup dengan gaya hidup hedonis adalah individu yang memandang secara positif mengenai kesenangan dan akan mengambil atau memanfaatkan kesempatan sekecil apapun untuk mencapai kesenangan yang diharapkan.

Dalam penelitiannya Felicia, dkk (2014) menemukan bahwa terdapat hubungan positif antara gaya hidup hedonisme dengan kecenderungan perilaku pembelian kompulsif. Semakin tinggi gaya hidup hedonisme, maka semakin tinggi kecenderungan perilaku pembelian kompulsif, dan sebaliknya. Pernyataan tersebut didukung oleh Eren, et al (2012) di dalam penelitiannya menemukan bahwa ada hubungan yang signifikan positif antara kecenderungan membeli kompulsif dengan nilai materialistik dan hedonis.

Selain celebrity worship, dan gaya hidup hedonis, hal yang dapat mempengaruhi terjadinya pembelian kompulsif adalah kecanduan internet atau internet addiction. Internet memiliki hubungan positif yang kuat dengan pembelian kompulsif online dan berbahaya bagi pembeli kompulsif (Bhatia, 2019). Dengan pertumbuhan e-commerce dan e-tailer, belanja online telah meningkat selama bertahun-tahun yang mengakibatkan ketagihan. Orang lebih suka berbelanja online karena mereka tidak harus bepergian ke mana pun, dan hanya dengan satu klik, produk dapat dikirim ke depan pintu mereka.

Pernyataan tersebut didukung oleh Mueller et al. dalam Bhatia (2019) yang mengatakan bahwa konsumen dengan kecenderungan membeli kompulsif secara berlebihan menggunakan Internet. Menurut Wulandari (2018) kecanduan internet memiliki pengaruh yang positif dan signifikan terhadap perilaku belanja kompulsif online. Individu yang terkena kecanduan internet memiliki potensi yang lebih besar untuk melakukan belanja kompulsif online. Omar et al. (2015) juga menyatakan bahwa penggunaan internet yang berlebihan akan membuat konsumen berpeluang lebih besar untuk melakukan pembelian kompulsif.

Seperti yang telah dikatakan sebelumnya, banyaknya online shop yang menjual beraneka ragam merchandise Kpop dapat menyebabkan terjadinya pembelian kompulsif terhadap produk-produk yang terkait dengan idola, contohnya seperti Uriharu Id. Online shop ini khusus menjual berbagai macam merchandise baik merchandise official maupun unofficial dari grup band Day6. Merchandise tersebut berupa album, poster, light stick, photocard, slogan, boneka, photobooks dan produk lainnya yang dirilis langsung oleh pihak agency dari band Day6 yaitu JYP Entertainment di Korea Selatan. Uriharu Id juga menyediakan jasa untuk pembelian tiket 
konser band Day6 dan jasa tabungan konser hingga menyelenggarakan event birthday caffe dan concert warming up untuk penggemar band Day6 "Myday".

Uriharu Id didirikan di Bogor pada tahun 2018 oleh Indah Margarina. Online shop ini bersaing dengan melakukan pre-order produk setiap kali pihak JYP Entertainment merilis merchandise dari band Day6 tersebut. Berdasarkan pengalaman dan pengamatan peneliti sepanjang tahun 2020, Uriharu Id merupakan online shop yang sudah terkenal dan sangat terpercaya, juga memiliki pengikut lebih dari sepuluh ribu di akun twitter mereka dan sebanyak lebih dari tiga ribu di akun instagram. Kelebihan lainnya dari Uriharu Id terdapat dalam pengiriman barang pre-order yang lebih cepat dibandingkan online shop lain. Uriharu Id biasanya melakukan pre-order merchandise dengan uang muka yang rendah dan seringkali membuka tabungan untuk perilisan merchandise yang akan datang, sehingga memudahkan penggemar yang ekonominya menengah kebawah. Hal tersebut dapat menjadi faktor yang mempengaruhi konsumen untuk melakukan pembelian barang yang kurang dibutuhkan demi mencapai kesenangan mereka.

\subsection{Pengaruh Celebrity Worship terhadap Pembelian Kompulsif}

Ayu dan Astiti (2020) mengatakan bahwa penggemar K-pop sering dianggap berlebihan dalam menyukai idola mereka. Dalam ilmu psikologi sikap ini disebut sebagai celebrity worship. Biasanya para penggemar tersebut melakukan berbagai kegiatan yang bertujuan untuk mendukung idolanya. Kegiatan tersebut memerlukan pengorbanan materi ataupun non materi baik dari segi waktu, tenaga maupun dana untuk menyenangkan idolanya. Misalnya dengan mengeluarkan banyak uang untuk membeli merchandise, album, tiket konser, dan produk produk yang berkaitan dengan idola mereka. Segala bentuk konsumsi yang dilakukan secara terus menerus atau berulang ini berkaitan dengan teori pembelian kompulsif dan celebrity worship. Jika dilihat dari sudut pandang penggemar hal tersebut merupakan bentuk pemujaan yang dilakukan terhadap idola karena mereka begitu mencintai idola mereka sehingga tidak memikirkan dampak yang akan muncul dimasa mendatang (Setiawan, 2016).

Menurut Maltby dalam Darfiyanti dan Putra (2012) Keterlibatan penggemar terhadap selebriti idola dalam tahap konsumsi mereka ini ada pada tahap intense personal feeling yang merupakan aspek refleksi dari perasaan intensif dan kompulsif yang dilakukan penggemar terhadap selebriti idola yang kemudian disebut sebagai tendensi obsesif fans.

Pernyataan tersebut didukung oleh Reeves, et al. (2012) yang mengatakan bahwa pembelian kompulsif secara signifikan berkorelasi dengan celebrity worship. Individu dengan tingkat celebrity worship tinggi percaya bahwa mereka memiliki ikatan atau hubungan khusus dengan selebriti. Orang-orang dengan celebrity worship cenderung melakukan pembelian secara kompulsif dengan melakukan pembelian produk-produk yang berkaitan dengan idola karena dengan hal tersebut dapat membuat penggemar merasa lebih dekat dengan idolanya.

Rahyuni, O. (2019) juga menemukan bahwa celebrity worship berpengaruh positif dan signifikan terhadap compulsive buying dengan nilai t-hitung sebesar 12,037 >1,985 dan taraf signifikansi $0,000<0,05$.

Kemudian didukung juga oleh Putri dan Rositawati (2020) di dalam penelitiannya menemukan bahwa terdapat pengaruh positif celebrity worship terhadap perilaku compulsive buying. Dimensi celebrity worship yang paling tinggi memiliki pengaruh terhadap perilaku 
compulsive buying adalah dimensi borderline-pathological sebesar 22,4\% kemudian intensepersonal sebesar $18,3 \%$ dan yang terakhir adalah entertainment social sebesar $14,6 \%$.

H1: Ada pengaruh positif dan signifikan antara celebrity worship terhadap pembelian kompulsif.

\subsection{Pengaruh Gaya Hidup Hedonis terhadap Pembelian Kompulsif}

Gaya hidup hedonis adalah suatu pola hidup seseorang yang beraktifitas untuk mencari kesenangan hidup, menghabiskan waktunya di luar rumah hanya untuk bersenang-senang dengan temannya, gemar membeli barang yang kurang dibutuhkan, dan selalu ingin menjadi pusat perhatian di lingkungan sekitarnya. (Nadzir dan Ingarianti, 2015). Gaya hidup sangat mempengaruhi bagaimana seorang individu menjalani kehidupannya dan hal itu sangat mencerminkan bagaimana pola hidup yang dijalankan. Gaya hidup seseorang sangat berpengaruh terhadap perilaku dan tindakan mereka termasuk perilaku pembeliannya.

Veenhoven dalam Felicia, dkk (2014) mengatakan individu yang hidup dengan gaya hidup hedonis adalah individu yang memandang secara positif mengenai kesenangan dan akan mengambil atau memanfaatkan kesempatan sekecil apapun untuk mencapai kesenangan yang diharapkan. Dalam penelitiannya Felicia, dkk (2014) menemukan bahwa terdapat hubungan positif antara gaya hidup hedonisme dengan kecenderungan perilaku pembelian kompulsif dengan koefisien sebesar $r=0,418$, nilai $p$ sebesar 0,000 artinya semakin tinggi gaya hidup hedonisme, maka semakin tinggi kecenderungan perilaku pembelian kompulsif, dan sebaliknya.

Pernyataan tersebut didukung oleh Eren, et al (2012) di dalam penelitiannya menemukan bahwa ada hubungan yang signifikan positif antara kecenderungan membeli kompulsif dengan nilai materialistik dan hedonis. Orang dengan kecenderungan membeli kompulsif yang lebih tinggi memiliki nilai materialistis dan hedonistik yang lebih tinggi. Pleasure dan enjoy adalah penentu utama nilai hedonis yang berhubungan dengan kecenderungan membeli kompulsif di kalangan mahasiswa Turkey.

Wijaya dan Yuniarto (2015) juga menemukan dalam penelitiannya bahwa Peningkatan variabel hedonisme, yang terdiri atas enjoy, sense of adventure, pleasure, self indulgent meningkatkan kecenderungan pembelian kompulsif pada masyarakat di Kota Malang.

Campbell dalam Eren, et al (2012) mengatakan bahwa orang-orang dengan nilai hedonis yang lebih tinggi, konsumen modern, cenderung menggunakan pendapatan berlebih mereka untuk keinginan baru mereka yang terus tumbuh untuk membeli. Pembeli dengan nilai hedonis yang lebih tinggi cenderung lebih responsif terhadap pengaruh promosi dalam pilihan produk mereka dan lebih sadar merek yang lebih memperhatikan nilai simbolisnya. Pembeli kompulsif yang membeli barang dengan keinginan yang tak tertahankan dan berulang kali menjadi segmen yang paling terpengaruh dari pengalaman berbelanja untuk kesenangan ini, dan hal ini dapat memicu nilai-nilai hedonis mereka.

H2: Ada pengaruh positif dan signifikan antara gaya hidup hedonis terhadap pembelian kompulsif.

\subsection{Pengaruh Kecanduan Internet terhadap Pembelian Kompulsif}

Dengan kemajuan teknologi, penggunaan Internet telah menyediakan saluran yang nyaman untuk membeli barang dan jasa. Internet memiliki hubungan positif yang kuat dengan 
pembelian kompulsif online dan berbahaya bagi pembeli kompulsif (Bhatia, 2019). Dengan pertumbuhan e-commerce dan e-tailer, belanja online telah meningkat selama bertahun-tahun yang mengakibatkan ketagihan. Orang lebih suka berbelanja online karena mereka tidak harus bepergian ke mana pun, dan hanya dengan satu klik, produk dapat dikirim ke depan pintu mereka.

Orang dewasa muda yang paham teknologi lebih suka menghabiskan waktu di Internet dan tidak dapat membayangkan hidup mereka tanpanya. Ponsel cerdas dan aplikasi belanja terbaru mendorong konsumen untuk membeli apapun secara kompulsif dan mudah. Belakangan ini, mode belanja ini menjadi populer di kalangan konsumen dengan kecenderungan membeli yang kompulsif.

Pernyataan tersebut didukung oleh Mueller et al. dalam Bhatia (2019) yang mengatakan bahwa konsumen dengan kecenderungan membeli kompulsif secara berlebihan menggunakan Internet. Menurut Wulandari (2018) kecanduan internet memiliki pengaruh yang positif dan signifikan terhadap perilaku belanja kompulsif online. Individu yang terkena kecanduan internet memiliki potensi yang lebih besar untuk melakukan belanja kompulsif online. Omar et al. (2015) juga menyatakan bahwa penggunaan internet yang berlebihan akan membuat konsumen berpeluang lebih besar untuk melakukan pembelian kompulsif.

Rahyuni, 0. (2019) dalam penelitiannya juga menemukan bahwa kecanduan internet berpengaruh secara positif dan signifikan terhadap compulsive buying dengan nilai t-hitung sebesar 2,156 > 1,985 dan taraf signifikansi 0,034<0,05.

H3: Ada pengaruh positif dan signifikan antara kecanduan internet terhadap pembelian kompulsif.

\section{Metode}

Pada penelitian ini menggunakan model regresi linier berganda. Teknik analisis data akan menggunakan SPSS dengan rumus regresi linier berganda sebagai berikut:

$\begin{array}{ll}\text { Keterangan: } & \\ \mathrm{Y} & \text { : Pembelian Kompulsif } \\ \alpha & \text { : Konstanta } \\ \beta_{1}, \beta_{2}, \beta_{3} & \text { : Koefisien Regresi } \\ \mathrm{X}_{1} & \text { : Celebrity Worship } \\ \mathrm{X}_{2} & \text { : Gaya Hidup Hedonis } \\ \mathrm{X}_{3} & \text { : Kecanduan Internet } \\ \mathrm{e} & \text { : Error Term }\end{array}$

$$
Y=\alpha+\beta_{1} X_{1}+\beta_{2} X_{2}+\beta_{3} X_{3}+e
$$

Responden penelitian ini adalah pelanggan yang pernah membeli merchandise band Day6 pada online shop Uriharu Id minimal 2 kali atau lebih. Pengumpulan sampel menggunakan propotional sampling. Kuesioner disebarkan kepada 110 pelanggan Uriharu Id.

Terdapat 3 indikator variabel celebrity worship yaitu entertainment social value, intense personal feeling, borderline pathological tendency (Maltby, dkk (2005). 3 indikator variabel gaya hidup hedonis yaitu minat, aktivitas, dan opini. (Well dan Tigert (1993) dalam Nadzir dan Ingarianti (2015). 5 indikator variabel kecanduan internet yaitu salience, penggunaan berlebihan, mengabaikan pekerjaan, kurang kontrol, dan mengabaikan kehidupan sosial (Prasojo, dkk (2018). 
Dan terdapat 5 indikator variabel pembelian kompulsif yaitu compulsion/drive to spend, feelings about shopping and spending, tendency to spend, dan dysfunctional spending, post-purchase guilt (Edward dan Elizabeth (1993).

Terdapat 9 item pada variabel celebrity worship, 4 item pada variabel gaya hidup hedonis, 5 item pada variabel kecanduan internet, dan 8 item pada variabel pembelian kompulsif. Item tersebut diukur menggunakan skala likert 1 - 5 dengan keterangan "sangat tidak setuju" dengan nilai 1 sampai "sangat setuju" dengan nilai 5.

Pengujian validitas dan realibilitas menggunakan SPSS 20 for windows untuk mendapatkan nilai Corrected Total Item Correlation untuk uji validitas dan nilai Cronbach's Alpha untuk uji reliabilitas. Item dikatakan valid apabila nilai Corrected Total Item Correlation lebih tinggi dari nilai $r$ tabel dan nilai Cronbach's Alpha yang merupakan koefisien reliabilitas diharuskan lebih besar dari 0.6

Uji asumsi klasik yang digunakan untuk mendukung model regresi dalam penelitian ini yaitu Uji Normalitas, Uji Mutikolinearitas, dan Uji Heteroskedastisitas.

\section{Hasil dan Pembahasan}

\subsection{Hasil}

Pada uji validitas semua item pernyataan dari variabel X1, X2, X3 dan Y menunjukkan nilai $r_{\text {hitung }}>r_{\text {tabel }} 0,361$ sehingga dapat ditarik kesimpulan bahwa item pertanyaan yang diujikan pada seluruh variabel dinyatakan valid. dan untuk uji realibilitas nilai Cronbach's Alpha semua variabel diatas 0.6 sehingga semua item yang digunakan dalam penelitian ini reliabel.

Tabel 1. Distribusi Frekuensi Variabel

\begin{tabular}{llll}
\hline Variable & Grand Mean & Min & Max \\
\hline Celebrity Worship & 3.17 & 1.83 & 4.34 \\
Gaya Hidup Hedonis & 3.01 & 2.51 & 3.52 \\
Kecanduan Internet & 3.40 & 2.72 & 3,90 \\
Pembelian Kompulsif & 2.91 & 1.86 & 4.30 \\
\hline
\end{tabular}

Sumber: data primer diolah peneliti 2021

Tabel 1 menggambarkan hasil deskriptif dari ketiga variabel yang diujikan dalam penelitian ini. Hasil perhitungan grand mean variabel celebrity worship sebesar 3,17 yang termasuk dalam kategori cukup tinggi, maka dapat disimpulkan bawa secara keseluruhan tingkatan celebrity worship yang dimiliki pelanggan Uriharu Id termasuk dalam kategori cukup tinggi. Nilai mean tertinggi yakni item X1.1 diperoleh nilai mean sebesar 4,34 yang berarti bahwa tingkatan celebrity worship pada pelanggan Uriharu Id sangat tinggi, dengan diwujudkan melalui responden yang menilai bahwa mempelajari kisah hidup selebriti favorit mereka merupakan hal yang menyenangkan. Hal tersebut juga berarti bahwa rata-rata pelanggan Uriharu Id masih dalam tahap entertainment social value dan belum benar-benar sampai tahap borderline pathological tendency, hal ini dibuktikan dengan hasil dari item dengan nilai mean terendah yakni item X1.6 diperoleh nilai mean sebesar 1,83 yang menjelaskan bahwa jika pelanggan Uriharu Id cukup beruntung untuk bertemu selebriti 
favoritnya, dan meminta mereka untuk melakukan sesuatu yang ilegal sebagai bantuan, mereka tidak akan melakukannya.

Hasil perhitungan grand mean variabel gaya hidup hedonis sebesar 3,01 yang termasuk dalam kategori cukup tinggi, maka dapat disimpulkan bahwa gaya hidup hedonis yang dimiliki pelanggan Uriharu Id secara keseluruhan termasuk dalam kategori cukup tinggi. Item dengan nilai mean tertinggi yakni item X2.13 diperoleh nilai mean sebesar 3,52 yang berarti bahwa gaya hidup hedonis pada pelanggan Uriharu Id termasuk dalam kategori tinggi, dengan diwujudkan melalui responden yang menilai bahwa belanja di online shop Uriharu Id adalah salah satu cara mereka untuk bersantai. Selain itu item dengan nilai mean terendah yakni item X2.10 diperoleh nilai mean sebesar 2,51 yang menunjukan bahwa pelanggan berbelanja di online shop Uriharu Id bukan semata-mata untuk mengikuti tren.

Hasil perhitungan grand mean variabel kecanduan internet sebesar 3,40 yang termasuk dalam kategori tinggi, maka dapat disimpulkan bahwa tingkat kecanduan internet yang dimiliki pelanggan Uriharu Id secara keseluruhan termasuk dalam kategori tinggi. Item dengan nilai mean tertinggi yakni item X3.17 diperoleh nilai mean sebesar 3,90 yang berarti bahwa tingkat kecanduan internet pada pelanggan Uriharu Id termasuk dalam kategori tinggi, dengan diwujudkan melalui responden yang menilai bahwa pelanggan Uriharu Id sering menghabiskan waktu mereka untuk online. Selain itu item dengan nilai mean terendah yakni item X3.18 diperoleh nilai mean sebesar 2,72 yang menunjukan bahwa pelanggan online shop Uriharu Id lebih senang menghabiskan waktu bersama teman dibandingkan main internet.

Hasil perhitungan grand mean variabel pembelian kompulsif sebesar 2,91 yang termasuk dalam kategori cukup tinggi, maka dapat disimpulkan bawa secara keseluruhan pembelian kompulsif yang dilakukan pelanggan Uriharu Id termasuk dalam kategori cukup tinggi. Item dengan nilai mean tertinggi yakni item Y.21 diperoleh nilai mean sebesar 4,30 yang berarti bahwa pembelian kompulsif yang dilakukan pelanggan pada online shop Uriharu Id termasuk dalam kategori sangat tinggi, dengan diwujudkan melalui responden yang menilai bahwa mereka merasa puas dan bahagia setelah berbelanja pada online shop Uriharu Id. Selain itu item dengan nilai mean terendah yakni item Y.25 diperoleh nilai mean sebesar 1,86 yang menunjukan bahwa responden membeli merchandise band Day6 pada online shop Uriharu Id karena mereka mampu membelinya.

\subsubsection{Uji Asumsi Klasik}

Uji Normalitas menggunakan Kolmogrov Smirrnov dengan perolehan hasil uji normalitas memiliki nilai signifikansi 0,956 > 0,05, maka dapat disimpulkan bahwa nilai residual terdistribusi normal.

Uji Multikolinearitas dapat dilihat dari nilai Tolerance-VIF masing-masing variabel independen. Diperoleh nilai tolerance variabel celebrity worship adalah 0,707 > dari 0,10 dan nilai VIF adalah $1,413<$ dari 10 , variabel gaya hidup hedonis adalah $0,766>$ dari 0,10 dan nilai VIF adalah 1,306 < dari 10, dan variabel kecanduan internet adalah 0,797 > dari 0,10 dan nilai VIF adalah 1,254 < dari 10. Maka dapat disimpulkan bahwa tidak terjadi multikolinieritas pada model regresi. 
Uji Heteroskedastisitas menggunakan Uji Glegser. Pada uji glegser diperoleh nilai signifikan seluruh variabel bebas $\mathrm{X}_{1}, \mathrm{X}_{2}$, dan $\mathrm{X}_{3}$ di atas 0,05. Maka dapat disimpulkan bahwa tidak terjadi heteroskedastisitas

Tabel 2. Hasil Analisis Regresi Berganda

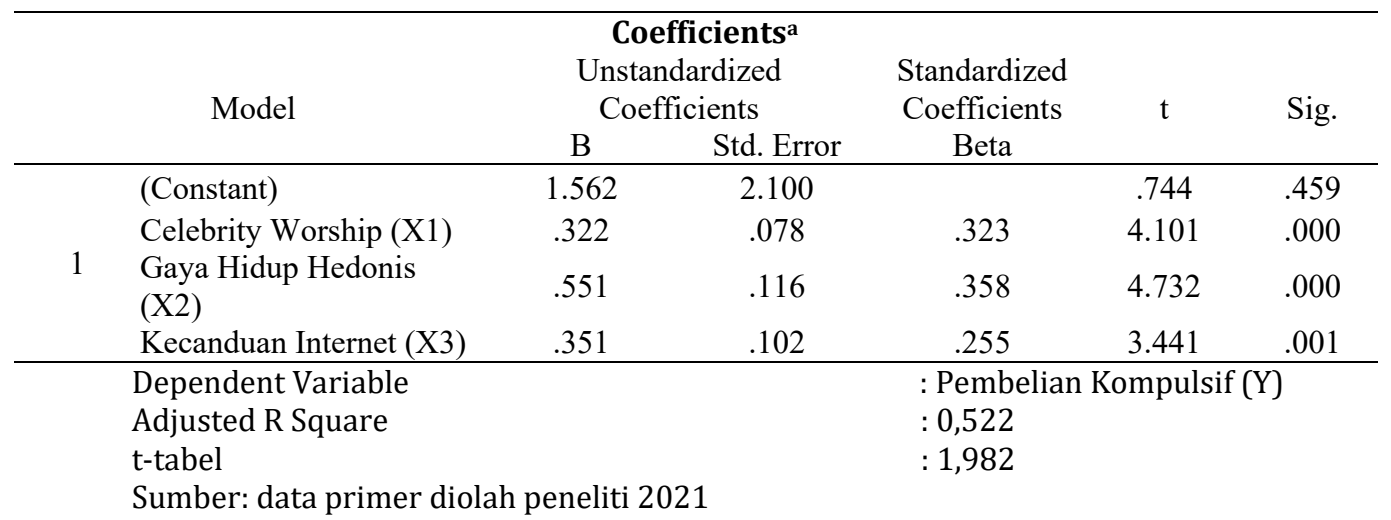

\subsubsection{Analisis Regresi Linear Berganda}

Berdasarkan hasil analisis data dengan menggunakan SPSS 20 pada table 2 diatas, maka diperoleh nilai constanta sebesar 1.562 sedangkan nilai coefficients Celebrity Worship (X1) sebesar 0,322, nilai coefficients Gaya Hidup Hedonis (X2) sebesar 0,551, dan nilai coefficients Kecanduan Internet (X3) sebesar 0,351. Sehingga dalam fungsi regresinya diperoleh persamaan sebagai berikut:

$$
\begin{gathered}
Y=\alpha+\beta_{1} X_{1}+\beta_{2} X_{2}+\beta_{3} X_{3}+e \\
Y=1,562+0,322 X_{1}+0,551 X_{2}+0,351 X_{3}+e
\end{gathered}
$$

Persamaan regresi diatas memperlihatkan hubungan antara variabel independent dengan variabel dependent secara parsial, dari persamaan tersebut dapat diambil kesimpulan bahwa:

Jika variabel X1 (Celebrity Worship) mengalami kenaikan satuan sebesar 1, dengan asumsi variabel lainnya konstan, maka variabel Y (Pembelian Kompulsif) akan mengalami kenaikan sebesar 0,322. Sebaliknya ketika X1 mengalami penurunan satuan sebesar 1 maka Y akan mengalami penurunan sebesar 0,322 .

Jika variabel X2 (Gaya Hidup Hedonis) mengalami kenaikan satuan sebesar 1, dengan asumsi variabel lainnya konstan, maka variabel Y (Pembelian Kompulsif) akan mengalami kenaikan sebesar 0,551. Sebaliknya ketika X2 mengalami penurunan satuan sebesar 1 maka Y akan mengalami penurunan sebesar 0,551 .

Jika variabel X3 (Kecanduan Internet) mengalami kenaikan satuan sebesar 1, dengan asumsi variabel lainnya konstan, maka variabel Y (Pembelian Kompulsif) akan mengalami kenaikan sebesar 0,351. Sebaliknya ketika X3 mengalami penurunan satuan sebesar 1 maka Y akan mengalami penurunan sebesar 0,351. 
Tabel 3. Hasil Adjust R Square

\begin{tabular}{|c|c|c|c|c|}
\hline \multicolumn{5}{|c|}{ Model Summary ${ }^{b}$} \\
\hline Model & $\mathrm{R}$ & R Square & $\begin{array}{l}\text { Adjusted R } \\
\text { Square }\end{array}$ & $\begin{array}{l}\text { Std. Error of the } \\
\text { Estimate }\end{array}$ \\
\hline 1 & $.731^{\mathrm{a}}$ & .535 & .522 & 3.346 \\
\hline $\begin{array}{l}\text { a. Pred } \\
\text { Hedon } \\
\text { b. Dep } \\
\text { Sumbe }\end{array}$ & $\begin{array}{l}\text { ors: }(\mathrm{C} \\
\text { X2), C } \\
\text { dent } \mathrm{Va} \\
\text { data pr }\end{array}$ & $\begin{array}{l}\text { nt), Kecanc } \\
\text { ty Worship } \\
\text { e: Pembelia } \\
\text { diolah pen }\end{array}$ & $\begin{array}{l}\text { an Internet } \\
\text { X1) } \\
\text { Kompulsif ( } \\
\text { ti } 2021\end{array}$ & Gaya Hidup \\
\hline
\end{tabular}

Berdasarkan table 3 tersebut dapat dilihat bahwa nilai Adjust R square sebesar 0,522 dimana nilai tersebut tergolong tinggi yang menandakan bahwa variabel bebas celebrity worship, gaya hidup hedonis, dan kecanduan internet berpengaruh sebesar 52,2\% terhadap variabel terikat pembelian kompulsif. Kemudian faktor lainnya dipengaruhi oleh variabel lain diluar penelitian ini.

\subsubsection{Uji t}

Uji t dilakukan dengan cara membandingkan antara t-hitung dan t-tabel dengan taraf signifikansi 5\% atau 0.05 dan nilai t-tabel 1,987.

Berdasarkan hasil dari tabel 2 dapat disimpulkan:

Pengaruh Celebrity Worship (X1) terhadap Pembelian Kompulsif (Y). Berdasarkan Tabel 2 diketahui thitung 4,101 $>t_{\text {tabel }} 1,982$ atau signifikansi $0,000<0,05$, maka $\mathrm{H}_{1}$ diterima. Dengan demikian terdapat pengaruh positif dan signifikan secara parsial variabel Celebrity Worship (X1) terhadap Pembelian Kompulsif (Y)

Pengaruh Gaya Hidup Hedonis (X2) terhadap Pembelian Kompulsif (Y) Berdasarkan Tabel 2 diketahui $t_{\text {hitung }} 4,732>t_{\text {tabel }} 1,982$ atau signifikansi $0,000<0,05$, maka $\mathrm{H}_{2}$ diterima. Dengan demikian terdapat pengaruh positif dan signifikan secara parsial variabel Gaya Hidup Hedonis (X2) terhadap Pembelian Kompulsif (Y)

Pengaruh Kecanduan Internet (X3) terhadap Pembelian Kompulsif (Y) Berdasarkan Tabel 2 diketahui $t_{\text {hitung }} 3,441>t_{\text {tabel }} 1,982$ atau signifikansi $0,001<0,05$, maka $\mathrm{H}_{3}$ diterima. Dengan demikian terdapat pengaruh positif dan signifikan secara parsial variabel Kecanduan Internet (X3) terhadap Pembelian Kompulsif (Y)

\subsection{Pembahasan}

\subsubsection{Deskripsi variabel Celebrity Worship}

Menurut Maltby, et al. (2003) celebrity worship adalah perilaku obsesi pada individu untuk terlibat secara penuh di setiap kehidupan idolanya, sehingga terbawa dalam kehidupan sehari-hari pada individu tersebut. Keterlibatan terhadap selebriti dibagi menjadi tiga aspek yang digunakan sebagai acuan dalam mengukur intensitas celebrity worship yang terdiri dari entertainment social value, intense personal feeling, dan borderline pathological tendency yang dijabarkan menjadi 9 (sembilan) item pertanyaan. Dari 9 (sembilan) item pertanyaan tersebut, indikator entertainment social value, pada item X1.1 memiliki nilai mean tertinggi 
dibandingkan dengan item-item lain, yakni sebesar 4,34. Artinya item X1.1 dengan pernyataan "Mempelajari kisah hidup selebriti favorit saya sangatlah menyenangkan", menunjukkan bahwa tingkatan celebrity worship pada tahap entertainment social value yang dimiliki oleh pelanggan Uriharu Id sangat tinggi, yang artinya kebanyakan pelanggan Uriharu Id baru memasuki tahapan awal celebrity worship, dimana mereka aktif melakukan pencarian informasi yang berkaitan dengan band Day6 dengan menggunakan media sebagai sarananya. Maka dari itu item ini memiliki kontribusi terbesar terhadap celebrity worship.

Pada indikator intense personal feeling sebagian besar responden paling banyak memberi jawaban setuju pada item X1.4 dengan nilai mean sebesar 3,62 sehingga masuk dalam kategori tinggi pada kelas interval, dengan pernyataan "Ketika sesuatu yang baik terjadi pada selebriti favorit saya, saya merasa itu terjadi pada saya". Artinya tingkatan celebrity worship yang dimiliki pelanggan Uriharu Id pada tahapan intense personal feeling termasuk dalam kategori tinggi, dimana pada tahapan ini sebagian besar pelanggan Uriharu Id mulai memiliki perasaan intensif dan kompulsif sehingga menyebabkan mereka menjadi memiliki kebutuhan untuk mengetahui segala sesuatu tentang band Day6. Pelanggan Uriharu Id yang juga merupakan penggemar dari band Day6, mulai memiliki hubungan parasosial atau satu arah terhadap idolanya tersebut.

Meskipun tingkatan celebrity worship pada tahap entertainment social value dan intense personal feeling yang dimiliki pelanggan Uriharu Id sudah dalam kategori tinggi, namun terdapat satu indikator dengan nilai item terendah dibandingkan dengan item-item pada indikator yang lain, yaitu pada indikator borderline pathological tendency. Indikator ini merupakan tingkatan yang paling parah dari dari kedua hubungan lainnya, dimana fans menjadi irasional dan memiliki pemikiran yang tidak terkontrol. Item pada indikator ini yakni X1.6 dengan nilai mean 1,83 yang termasuk dalam kategori rendah dengan pernyataan "Jika saya cukup beruntung untuk bertemu selebriti favorit saya, dan dia meminta saya untuk melakukan sesuatu yang illegal sebagai bantuan, saya mungkin akan melakukannya". Hal ini menunjukan bahwa rata-rata pelanggan Uriharu Id belum memasuki tingkatan celebrity worship pada tahap borderline pathological tendency, yang artinya para pelanggan Uriharu Id masih memiliki perilaku rasional terhadap band Day6. Maka dari itu item tersebut memiliki kontribusi paling rendah terhadap celebrity worship pada pelanggan online shop Uriharu Id.

Dapat disimpulkan bahwa tingkatan celebrity worship yang dimiliki pelanggan online shop Uriharu Id, termasuk dalam kategori sangat tinggi pada tahap entertainment social value, kategori tinggi pada tahap intense personal feeling, dan rendah pada tahap borderline pathological tendency. Maka secara keseluruhan termasuk dalam kategori cukup tinggi dengan nilai grand mean sebesar 3,17.

\subsubsection{Deskripsi Variabel Gaya Hidup Hedonis}

Menurut Nadzir dan Ingarianti (2015) Gaya hidup hedonis merupakan suatu pola hidup seseorang yang beraktifitas untuk mencari kesenangan hidup, menghabiskan waktu di luar rumah untuk bersenang-senang dengan temannya, gemar membeli barang yang kurang dibutuhkan, dan selalu ingin menjadi pusat perhatian di lingkungan sekitarnya. Salah satu contohnya seperti membeli merchandise band Day6 pada online shop Uriharu Id. Gaya hidup hedonis pada penelitian ini memiliki 3 (tiga) alat ukur indikator yaitu minat (interest), aktivitas (activities), dan opini (opinion). Dari 3 (tiga) indikator tersebut dijabarkan menjadi 4 (empat) 
item pernyataan. Salah satunya item X2.13 dengan pernyataan "Menurut saya belanja adalah salah satu cara untuk bersantai", memiliki nilai mean tertinggi yaitu 3,52 yang termasuk dalam kategori tinggi. Hal ini menunjukkan bahwa berbelanja pada online shop Uriharu Id merupakan salah satu cara pelanggan untuk bersantai. Artinya bahwa opini pelanggan terhadap produk produk yang dijual oleh Uriharu Id sudah baik dan item tersebut memiliki kontribusi terbesar terhadap gaya hidup hedonis pada pelanggan Uriharu Id.

Sedangkan item X2.10 dengan pernyataan "Saya berbelanja untuk mengikuti tren" ini memiliki nilai mean 2,51 yang artinya item ini memiliki kontribusi terendah terhadap gaya hidup hedonis pada pelanggan Uriharu Id, namun item ini masih dalam kategori cukup tinggi. Maka dapat disimpulkan bahwa gaya hidup hedonis yang dilakukan oleh pelanggan online shop Uriharu Id, secara keseluruhan termasuk dalam kategori cukup tinggi dengan nilai grand mean sebesar 3,01 .

\subsubsection{Deskripsi Variabel Kecanduan Internet}

Menurut Kandell (dalam Wulandari, 2018) kecanduan internet yaitu ketergantungan psikologis pada internet, apapun aktivitasnya sekalinya terkoneksi pada internet yang dapat meliputi segala macam hal yang berhubungan dengan internet seperti jejaring sosial, e-mail, pornografi, judi online, game online, chatting, dan lain-lain. Sedangkan menurut Brenner (dalam Rahyuni, 2019) individu dapat mengalami kecanduan ketika menghabiskan waktunya selama 19 jam per minggu, dimana dalam penggunaannya individu menunjukkan adanya keinginan untuk menambah waktu penggunaan internet, adanya ketidaknyamanan yang dirasakan ketika individu tersebut tidak menggunakan internet, dan adanya keinginan untuk secara terus-menerus menggunakan internet. Kecanduan internet dalam penelitian ini dapat diukur dengan menggunakan 5 (lima) indikator The Internet Addiction Test (IAT) yang di kembangkan oleh Dr. Kimberly Young pada tahun 1998 dan telah di adaptasi oleh Prasojo, dkk (2018) yaitu, (1) salience, (2) penggunaan berlebihan, (3) mengabaikan pekerjaan, (4) kurang kontrol, (5) mengabaikan kehidupan sosial.

Berdasarkan hasil analisis statistik deskriptif yang telah dijabarkan, menunjukkan bahwa tingkat kecanduan internet yang dimiliki pelanggan Uriharu Id secara keseluruhan termasuk dalam kategori tingi, hal ini berdasarkan grand mean dengan skor 3,40. Dari kelima indikator diatas dijabarkan menjadi 5 (lima) item pernyataan. Salah satunya item X3.17 dengan pernyataan "Saya sering menghabiskan banyak waktu untuk online", memiliki nilai mean tertinggi yaitu 3,90 yang termasuk dalam kategori tinggi. Hal ini menunjukkan bahwa sebagian besar pelanggan online shop Uriharu Id banyak menggunakan waktunya untuk online. Pelanggan kurang mengontrol penggunaan internet yang mereka lakukan sehingga dapat menyebabkan dampak negatif dikemudian hari. Artinya bahwa item tersebut memiliki kontribusi terbesar terhadap kecanduan internet pada pelanggan Uriharu Id. Sedangkan item X3.18 dengan pernyataan "Saya lebih senang main internet dibandingkan menghabiskan waktu bersama teman" ini memiliki nilai mean 2,72 yang artinya item ini memiliki kontribusi terendah terhadap tingkat kecanduan internet pada pelanggan Uriharu Id, namun item ini masih dalam kategori cukup tinggi. Hal ini juga berarti bahwa pelanggan Uriharu Id mengabaikan kehidupan sosialnya karena terlalu banyak menghabiskan waktunya bermain internet. 


\subsubsection{Deskripsi Variabel Pembelian Kompulsif}

Menurut Putri dan Rositawati (2020) Pembelian Kompulsif merupakan suatu tindakan seseorang dalam mengambil keputusan untuk membeli barang bukan hanya karena kebutuhannya, melainkan juga demi pemuasan keinginannya yang dilakukan secara berlebihan, kronis, dan berulang-ulang sebagai representatif perasaan negatif atau untuk mengurangi perasaan negatif, yang dilakukan dengan cara membeli merchandise band Day6 secara berulang-ulang pada online shop Uriharu Id. Pembelian kompulsif pada penelitian ini memiliki 5 (lima) alat ukur indikator yaitu compulsion/drive to Spend, feelings about shopping and spending, tendency to spend, dysfunctional spending, post-purchase guilt.

Berdasarkan hasil analisis statistik deskriptif yang telah dijabarkan sebelumnya untuk keseluruhan item pernyataan pembelian kompulsif, responden memberikan jawaban yang beragam, mulai dari pilihan jawaban sangat setuju sampai pilihan sangat tidak setuju. Tetapi total rata-rata jawaban responden menunjukan bahwa pembelian kompulsif yang dilakukan oleh pelanggan Uriharu Id termasuk dalam kategori cukup tinggi dengan nilai grand mean 2,91. Dari 5 (lima) indikator diatas dijabarkan menjadi 8 (delapan) item pernyataan. Salah satunya item Y.21 dengan pernyataan "Saya merasa puas dan bahagia setelah berbelanja", memiliki nilai mean tertinggi yaitu 4,30 yang termasuk dalam kategori sangat tinggi. Hal ini menunjukkan bahwa pelanggan merasa puas dan bahagia setelah membeli merchandise band Day6 pada online shop Uriharu Id. Artinya bahwa pelanggan Uriharu Id sangat mengutamakan feelings about shopping and spending atau kenikmatan yang dirasakan saat berbelanja atau membeli merchandise dan produk - produk lainnya terkait band Day6 pada online shop Uriharu Id. Maka item tersebut memiliki kontribusi terbesar terhadap pembelian kompulsif pada pelanggan Uriharu Id.

Akan tetapi dari 8 item pertanyaan tersebut terdapat satu item yang memperoleh jawaban paling rendah dari mayoritas responden yaitu item Y.25 dengan pernyataan "Saya membeli merchandise band Day6 meskipun saya tidak mampu membelinya", item ini memiliki nilai mean 1,86 yang termasuk dalam kategori rendah. Artinya bahwa pelanggan Uriharu Id membeli merchandise band Day6 karena mereka mampu membelinya. Maka dapat dikatakan bahwa item ini memiliki kontribusi terendah terhadap pembelian kompulsif pada pelanggan Uriharu Id.

\subsubsection{Pengaruh Celebrity Worship terhadap Pembelian Kompulsif}

Berdasarkan analisis data yang telah dijelaskan sebelumnya, dapat dilihat bahwa nilai signifikansi variabel celebrity worship sebesar 0,000 < 0,05 dan nilai thitung 4,101 > tabel 1,982 terbukti bahwa secara parsial hasil uji variabel celebrity worship berpengaruh positif dan signifikan terhadap pembelian kompulsif. Hal tersebut menunjukan hipotesis $1\left(\mathrm{H}_{1}\right)$ diterima, yaitu ada pengaruh positif dan signifikan antara celebrity worship terhadap pembelian kompulsif merchandise band Day6 pada online shop Uriharu Id.

Hal tersebut didukung oleh penelitian sebelumnya yang relevan dengan penelitian ini yaitu penelitian yang dilakukan oleh Reeves, et al. (2012) yang mengatakan bahwa pembelian kompulsif secara signifikan berkorelasi dengan celebrity worship. Individu dengan tingkat celebrity worship tinggi percaya bahwa mereka memiliki ikatan atau hubungan khusus dengan

selebriti. Kemudian didukung juga oleh Putri dan Rositawati (2020) didalam penelitiannya 
menemukan bahwa terdapat pengaruh positif celebrity worship terhadap perilaku compulsive buying.

Berdasarkan hasil penelitian yang diperoleh menandakan bahwa sikap pemujaan terhadap selebriti (celebrity worship) yang dimiliki oleh pelanggan online shop Uriharu Id yang juga merupakan penggemar dari band Day6 ini, dapat mendorong mereka untuk melakukan pembelian kompulsif terhadap merchandise atau produk lainnya yang berkaitan dengan band Day6 pada online shop Uriharu Id. Orang-orang dengan celebrity worship cenderung melakukan pembelian secara kompulsif dengan melakukan pembelian produk - produk yang berkaitan dengan idola karena dengan hal tersebut dapat membuat penggemar merasa lebih dekat dengan idolanya, seperti halnya yang dilakukan oleh pelanggan Uriharu Id.

Segala bentuk konsumsi yang dilakukan secara terus menerus atau berulang ini berkaitan dengan teori pembelian kompulsif dan celebrity worship. Jika dilihat dari sudut pandang penggemar hal tersebut merupakan bentuk pemujaan yang dilakukan terhadap idola karena mereka begitu mencintai idola mereka sehingga tidak memikirkan dampak yang akan muncul dimasa mendatang (Setiawan, 2016).

Dapat disimpulkan bahwa variabel celebrity worship yang terdiri dari entertainment social value, intense personal feeling, dan borderline pathological tendency berpengaruh positif dan signifikan terhadap pembelian merchandise band Day6 pada online shop Uriharu Id.

\subsubsection{Pengaruh Gaya Hidup Hedonis terhadap Pembelian Kompulsif}

Berdasarkan analisis data yang telah dijelaskan sebelumnya, dapat dilihat bahwa nilai signifikansi variabel gaya hidup hedonis sebesar $0,000<0,05$ dan nilai $t_{\text {hitung }} 4,732>t_{\text {tabel }} 1,982$ terbukti bahwa secara parsial hasil uji variabel gaya hidup hedonis berpengaruh positif dan signifikan terhadap pembelian kompulsif. Hal tersebut menunjukan hipotesis $2\left(\mathrm{H}_{2}\right)$ diterima, yaitu ada pengaruh positif dan signifikan antara gaya hidup hedonis terhadap pembelian kompulsif merchandise band Day6 pada online shop Uriharu Id. Semakin tinggi gaya hidup hedonis yang dimiliki pelanggan maka semakin tinggi pula kecederungan pembelian kompulsif terhadap merchandise band Day6 pada online shop Uriharu Id, begitu juga sebaliknya.

Hal tersebut didukung oleh penelitian sebelumnya yang relevan dengan penelitian ini yaitu penelitian yang dilakukan oleh Felicia, dkk (2014) menemukan bahwa terdapat hubungan positif antara gaya hidup hedonisme dengan kecenderungan perilaku pembelian kompulsif dengan koefisien sebesar $r=0,418$, nilai $p$ sebesar 0,000 artinya semakin tinggi gaya hidup hedonisme, maka semakin tinggi kecenderungan perilaku pembelian kompulsif, dan sebaliknya.

Berdasarkan hasil penelitian yang diperoleh, gaya hidup seseorang sangat berpengaruh terhadap perilaku dan tindakan mereka termasuk perilaku pembeliannya, yang berkaitan dengan minat, aktivitas dan opini pelanggan Uriharu Id terhadap suatu produk. Item opini memiliki nilai tertinggi yang artinya bahwa opini pelanggan terhadap produk - produk yang

dijual oleh Uriharu Id sudah baik sehingga menyebabkan mereka melakukan pembelian kompulsif terhadap merchandise dan produk - produk lain terkait band day6. Hal ini menandakan bahwa gaya hidup hedonis yang dimiliki oleh pelanggan Uriharu Id mempengaruhi mereka untuk melakukan pembelian barang-barang yang kurang dibutuhkan 
secara terus menerus hanya untuk memuaskan keinginan dan rasa senang mereka, seperti membeli merchandise band Day6 berulang kali pada online shop Uriharu Id.

Veenhoven dalam Felicia, dkk (2014) mengatakan individu yang hidup dengan gaya hidup hedonis adalah individu yang memandang secara positif mengenai kesenangan dan akan mengambil atau memanfaatkan kesempatan sekecil apapun untuk mencapai kesenangan yang diharapkan. Campbell dalam Eren, et al (2012) juga mengatakan bahwa orang-orang dengan nilai hedonis yang lebih tinggi, konsumen modern, cenderung menggunakan pendapatan berlebih mereka untuk keinginan baru mereka yang terus tumbuh untuk membeli. Pembeli kompulsif yang membeli barang dengan keinginan yang tak tertahankan dan berulang kali menjadi segmen yang paling terpengaruh dari pengalaman berbelanja untuk kesenangan ini.

Dapat disimpulkan bahwa variabel gaya hidup hedonis yang terdiri dari minat (interest), aktivitas (activities), dan opini (opinion) berpengaruh positif dan signifikan terhadap pembelian merchandise band Day6 pada online shop Uriharu Id.

\subsubsection{Pengaruh Kecanduan Internet terhadap Pembelian Kompulsif}

Berdasarkan analisis data yang telah dijelaskan sebelumnya, dapat dilihat bahwa nilai signifikansi variabel kecanduan internet sebesar 0,001 $<0,05$ dan nilai $t_{\text {hitung }} 3,441>t_{\text {tabel }}$ 1,982 terbukti bahwa secara parsial hasil uji variabel kecanduan internet berpengaruh positif dan signifikan terhadap pembelian kompulsif. Hal tersebut menunjukan hipotesis $3\left(\mathrm{H}_{3}\right)$ diterima, yaitu ada pengaruh positif dan signifikan antara kecanduan internet terhadap pembelian kompulsif merchandise band Day6 pada online shop Uriharu Id. Semakin tinggi tingkat kecanduan internet yang dimiliki pelanggan maka semakin tinggi pula kecenderungan untuk melakukan pembelian kompulsif terhadap merchandise band Day6 pada online shop Uriharu Id, begitupun sebaliknya.

Hal tersebut didukung oleh penelitian sebelumnya yang relevan dengan penelitian ini yaitu penelitian yang dilakukan oleh Wulandari (2018), mengatakan bahwa kecanduan internet memiliki pengaruh yang positif dan signifikan terhadap perilaku belanja kompulsif online. Individu yang terkena kecanduan internet memiliki potensi yang lebih besar untuk melakukan belanja kompulsif online. Omar et al. (2015) juga menyatakan bahwa penggunaan internet yang berlebihan akan membuat konsumen berpeluang lebih besar untuk melakukan pembelian kompulsif.

Berdasarkan hasil penelitian yang diperoleh menandakan bahwa perilaku kecanduan internet yang dilakukan oleh pelanggan Uriharu Id dapat menyebabkan mereka melakukan pembelian kompulsif terhadap suatu produk secara online, seperti pembelian merchandise band Day6 yang dilakukan pada online shop Uriharu Id. Individu lebih banyak menghabiskan waktunya untuk online, juga suka berbelanja online karena mereka tidak harus bepergian ke mana pun, dan hanya dengan satu klik, produk dapat dikirim ke depan pintu mereka. Juga dengan adanya pertumbuhan e-commerce, e-tailer, dan belanja online yang mengakibatkan ketagihan. Pernyataan tersebut didukung Mueller et al. dalam Bhatia (2019) mengatakan bahwa konsumen dengan kecenderungan membeli kompulsif secara berlebihan menggunakan Internet.

Kemudian berdasarkan hasil analisis statistik deskriptif pada bab sebelumnya ditemukan bahwa pelanggan Uriharu Id kurang mengontrol penggunaan internet yang mereka 
lakukan dan mengabaikan kehidupan sosialnya karena terlalu banyak menghabiskan waktunya untuk bermain internet sehingga peluang mereka untuk melakukan pembelian kompulsif terhadap merchandise dan produk - produk lain terkait band Day6 menjadi lebih besar.

Dapat disimpulkan bahwa variabel kecanduan internet yang terdiri dari salience, penggunaan berlebihan, mengabaikan pekerjaan, kurang kontrol, dan mengabaikan kehidupan sosial berpengaruh positif dan signifikan terhadap pembelian merchandise band Day6 pada online shop Uriharu Id.

\section{Simpulan}

\subsection{Kesimpulan}

Berdasarkan hasil penelitian yang dilakukan menunjukan bahwa:

Berdasarkan hasil analisis statistik deskriptif tingkat celebrity worship pada pelanggan online shop Uriharu Id dapat dikategorikan cukup tinggi, gaya hidup hedonis dikategorikan cukup tinggi, kecanduan internet termasuk dalam kategori tinggi, dan pembelian kompulsif termasuk dalam kategori cukup tinggi.

Variabel celebrity worship terbukti secara parsial memiliki pengaruh positif dan signifikan terhadap variabel pembelian kompulsif.

Variabel gaya hidup hedonis terbukti secara parsial memiliki pengaruh positif dan signifikan terhadap variabel pembelian kompulsif.

Variabel kecanduan internet terbukti secara parsial memiliki pengaruh positif dan signifikan terhadap variabel pembelian kompulsif.

\subsection{Saran}

Bagi Pemilik Online Shop Uriharu Id. Berdasarkan kesimpulan yang diperoleh dari penelitian ini, diketahui walaupun semua hipotesis diterima dan semua variabel penelitian dapat dikatakan dalam keadaan yang baik, tapi ada aspek yang perlu diperhatikan lebih lanjut oleh owner Uriharu Id. Dari semua variabel yang menjadi fokus penelitian, didapatkan bahwa pembelian kompulsif pada pelanggan Uriharu Id memiliki nilai paling rendah, hal ini menunjukkan bahwa Uriharu Id belum berhasil secara maksimal dalam menarik pelanggan yang memiliki perilaku pembelian kompulsif terhadap merchandise band Day6 . Pembelian kompulsif sendiri merupakan konsumsi berlebihan, dan berulang-ulang terhadap pembelian merchandise band Day6 pada Uriharu Id. Bagi owner Uriharu Id disarankan untuk melakukan penjualan juga promosi melalui media online seperti e-commerce dan media sosial lainnya seperti instagram, twitter, facebook dan lainnya. Selain itu berikan juga kemudahan lainnya seperti akses melalui hp, dan pembayaran menggunakan e-money atau internet banking untuk mempermudah penjualan dan dapat meningkatkan penjualan merchandise dan produk lainnya yang berhubungan dengan band Day6. Sehingga dapat menarik lebih banyak pelanggan yang merupakan mahasiswa/pelajar perempuan.

Bagi Peneliti di Masa Mendatang Saran kepada peneliti selanjutnya diharapkan dapat mencari faktor lain selain celebrity worship, gaya hidup hedonis, dan kecanduan internet, yang 
dapat berpengaruh terhadap kecenderungan perilaku pembelian kompulsif dan lebih mengembangkan metode serta alat ukur yang akan digunakan dalam penelitian sehingga akan mendapatkan hasil yang lebih baik.

\section{Daftar Rujukan}

Ayu, N. W. R. S., \& Astiti, D. P. (2020). Gambaran Celebrity Worship Pada Penggemar K-Pop. Psikobuletin: Buletin Ilmiah Psikologi, 1(3), 203-210.

Bhatia, V. (2019). Impact of fashion interest, materialism and internet addiction on e-compulsive buying behaviour of apparel. Journal of Global Fashion Marketing, 10(1), 66-80.

Edwards, E. A. (1993). Development of a new scale for measuring compulsive buying behavior. Financial counseling and planning, 4(1), 67-84.

Egsaugm. (2020). Fenomena Korean wave di Indonesia. (https://egsa.geo.ugm.ac.id/2020/09/30/fenomenakorean-wave-di-indonesia/). diakses 20 Oktober 2020

Eren, S. S., Eroğlu, F., \& Hacioglu, G. (2012). Compulsive buying tendencies through materialistic and hedonic values among college students in Turkey. Procedia-Social and Behavioral Sciences, 58, 1370-1377.

Darfiyanti, D., \& Putra, M. G. B. A. (2012). Pemujaan terhadap idola pop sebagai dasar intimate relationship pada dewasa awal: Sebuah Studi Kasus. Jurnal psikologi kepribadian dan Sosial, 1(2).

Dewi, D. P. K. S., \& Indrawati, K. R. (2019). Gambaran celebrity worship pada penggemar K-Pop usia dewasa awal di Bali. Jurnal Psikologi Udayana, 6(2), 291-300.

Felicia, F., Elvinawaty, R., \& Hartini, S. (2014). Kecenderungan Pembelian Kompulsif: Peran Perfeksionisme dan Gaya Hidup Hedonistik. Psikologia: Jurnal Pemikiran dan Penelitian Psikologi, 9(3).

Horváth, C., \& Adıgüzel, F. (2018). Shopping enjoyment to the extreme: Hedonic shopping motivations and compulsive buying in developed and emerging markets. Journal of Business Research, 86, 300-310.

Larasati, D. (2018). Globalization on Culture and Identity: Pengaruh dan Eksistensi Hallyu (Korean-Wave) Versus Westernisasi di Indonesia. Jurnal Hubungan Internasional, 11(1), 109-120.

Lee, S., Park, J., \& Bryan Lee, S. (2016). The interplay of Internet addiction and compulsive shopping behaviors. Social Behavior and Personality: an international journal, 44(11), 1901-1912.

Maltby, J., Houran, J., \& McCutcheon, L. E. (2003). A clinical interpretation of attitudes and behaviors associated with celebrity worship. The Journal of nervous and mental disease, 191(1), 25-29.

Maltby, J., Giles, D. C., Barber, L., \& McCutcheon, L. E. (2005). Intense-personal celebrity worship and body image: Evidence of a link among female adolescents. British journal of health psychology, 10(1), 17-32.

Nadzir, M., \& Ingarianti, T. M. (2015). Psychological meaning of money dengan gaya hidup hedonis remaja. Seminar Psikologi \& Kemanusiaan. 582-596. Malang: Psychology Forum Umm.

O'Guinn, T. C., \& Faber, R. J. (1989). Compulsive buying: A phenomenological exploration. Journal of Consumer Research, 16, 147-157.

Omar, Nor Asiah., Wel, Che Aniza Che., Alam, Syed Shah., Nazri, Muhamad Azrin. (2015). Understanding Students Compulsive Buying of Apparel: An Empirical Study. Jurnal Personalia Pelajar. 18 (2). 107 113.

Prasojo, R. A., Maharani, D. A., \& Hasanuddin, M. 0. (2018). Mengujikan Internet Addiction Test (IAT) ke Responden Indonesia.

Putri, I. P., Liany, F. D. P., \& Nuraeni, R. (2019). K-Drama dan Penyebaran Korean Wave di Indonesia. ProTVF, 3(1), 68-80.

Putri, D. E., \& Rositawati, S. (2020). Pengaruh Celebrity Worship terhadap Perilaku Compulsive Buying pada Dewasa Awal Anggota Komunitas Baia Bandung.

Rahyuni, O. (2019). Pengaruh Celebrity Worship, Self Esteem dan Kecanduan Internet terhadap Compulsive Buying dalam Membeli Merchandise Idola K-pop pada Fans BTS di Kebumen.

Reeves, R. A., Baker, G. A., \& Truluck, C. S. (2012). Celebrity worship, materialism, compulsive buying and the empty self. Journal Psychology and Marketing, 29 (9), 67-87.

Setiawan, Y. (2016). Perilaku Konsumtif Penggemar Grup Idola JKT48 Dalam Fanbase WANI (Studi Kasus terhadap Enam Anggota Fanbase WANI) (Doctoral dissertation, Universitas Airlangga). 
Jurnal Ekonomi, Bisnis dan Pendidikan, 1(5), 2021, 452-469

Sugiyono, (2015). Metode Penelitian Kuantitatif kualitatif dan R \& D. Bandung: Alfabeta.

Tyas. (2017). Day6 resmi umumkan nama fandom yang terpilih dari hasil voting (http://hiburan.dreamers.id/article/63607/day6-resmi-umumkan-nama-fandom-yang-terpilih-darihasil-voting). diakses 20 Oktober 2020

Universitas Negeri Malang. (2017). Pedoman Penulisan Karya Ilmiah Universitas Negeri Malang.

Wijaya, A. P., \& Yuniarinto, A. (2015). Pengaruh Hedonisme dan Materialisme Terhadap Kecenderungan Pembelian Kompulsif Di Kota Malang. Jurnal Ilmiah Mahasiswa FEB, 4(1).

Wulandari, K. (2018). Pengaruh Kecanduan Internet dan Materialisme terhadap Perilaku Pembelian Kompulsif Online (Doctoral dissertation, Udayana University). 